\title{
Versions of Post Avant-Garde Music
}

\author{
Sorana MĂNĂILESCU ${ }^{1}$
}

\begin{abstract}
The present paper is written in response to Christopher Norris's allegation in a famous essay, "Post-modernism - a guide for the perplexed," (Norris 2000) that, unlike literary postmodernism, characterized by an appeal to intelligence and intellectual effort from the reading public, musical postmodernism is impoverished in point of language and idea. This communication attempts to shed light on the complexity of musical compositions in the generic sphere of electroacoustic, timbral or computer-generated music, whose creators are at the same time theorists of their own language which requires a key to interpretation. Far from being minimalist, this post-avant-garde music has an interest in the history of musical styles, as titles such as the New Romanticism, New Interiority or New Expressionism also indicate the intention of crossing the borders of postmodernism. To what? This paper is an attempt to identify new directions by several prominent representatives.
\end{abstract}

Key-words: Post Avant-Garde, Musical Postmodernism, Cultural Theory, The New Complexity, The New Simplicity, Spectral Music, Archetypal Music

\section{Steps Away from the Avant-Garde}

An approach to postwar music in relation to the other arts is perfectly justified, as all artefacts are embedded in what past historians of culture used to call "spirit of the time," while contemporary cultural anthropologists speak of epistemological frame and stylistic matrix. It is only that Christopher Norris miss-matches musical and literary postmodernism, or, more exactly, he compares musical avant-garde (minimalism) to literary postmodernism. There was a minimalist movement in literature as well, represented by Raymond Carver, Frederick Barthelme, Cormac Mc Carthy, or Jay Maclnerney, among others. Their smallness of vision, simplicity and paucity of vocabulary, reductive syntax, absence of rhetorical devices are not just a matter of style but of a receiver-dependent poetics. John Cage is placing an inactive piano player in front of his instrument for a number of minutes, while the

\footnotetext{
${ }^{1}$ Transilvania University of Braşov, soranatupan@yahoo.com
} 
audience is expected to figure out the score ... On the contrary, World Music or the Kronos Quartet, through their appropriation of non-Western music, produce hybrids which bespeak the eclecticism of Postmodernism and its relish for excessive meaning (resulting from the overlay of distinct musical traditions European and non-European, folk or classical music, etc.), so that Viet Erlmann ventures to launch a new concept: the "global imagination" (Erlmann 1990).

It is true, through, that the unfavorable view taken by a cultural philosopher, Christopher Norris, of postmodernism in his 2000 essay ("Post-modernism - a guide for the perplexed") does not have as a context a musicological study, but one of theorizing the relationship between art and society, of holistic understanding of the present. The ideological projects of modernity - the cult of reason, of social, democratic reform - have been subjected to the critical assault of postmodernists who have seen in them the ideological source of social utopias installed through bloody revolutions and materialized in various forms of political totalitarianism. Postmodernism would thus mean, by contrast, the rejection of any fundamentalism, narrative, content orientation, reduction to ingenious, playful, parodic modes of reference to those utopias that turned into dystopias in many societies of the troubled twentieth century. Of course, in this case, we would not speak of a radically different aesthetic, but only of the appearance of some antilanguages within the same formal logic: atonality, timelessness, refusal of thematicism or representation. Norris, however, blames "postmodern music" (actually, he has in mind minimalism) even for the absence of such an agenda, postwar music degenerating into empty, meaningless, and repetitive mechanics:

Perhaps I would not really hope to dissuade you or to spoil your enjoyment by coming up with good reasons to think it bad music! On the other hand, I would want to say that the argument does not stop there. One can go beyond saying ' like it' or 'I don't like it', one can remark that much of this music is mindnumbingly repetitive, that it offers no aural or intellectual challenge, requires no effort of structural grasp or ability to follow a complex pattern of harmonic, tonal or rhythmic development (Norris 2000, 28).

Unlike Norris, we consider that the music of the last decades offers a spectacular picture of experiments in the possibilities of musical discourse, and, at the same time, an attempt to recover its significant function.

In his article, "Postmodern Eclecticism and the World Music Debate: The Politics of the Kronos Quartet" (Bennett 2005), David Bennett accuses the Kronos musicians of illicit appropriation of other nations' traditions, of enshrining them as alien, as the other of the West. On the contrary, by allowing African composers to 
write their own music for the Pieces of Africa album, Kronos engaged in a cultural dialogue, filtering the unadulterated foreign matter through their own sensibility. Postmodernist quotation instead of modernist refurbishing guarantees the integrity of the other's identity. Sometimes the dialogue establishes between musical discourse and some other medium - for instance, in Louis Andriessen's II Duce, for tape recorder (1973), II Prince, for two choirs and ensemble of winds (1974), or in De Staat (for ensemble), the intertext is born of the composer's own music and other discourses (political, philosophical), instruments being grouped on the stage face to face, as in a conversation.

If, in the spirit of Shenkerian analysis, we turn to the deep structure of contemporary music, we notice that the abstract algorithmic matrix of the music of Xenakis, the more complex but still mathematical generational model of Messiaen's transmutations of musical materials make room for an archetypal ontological model:

These common, unifying elements [...], which "overcome with seemingly inexplicable ease differences in language, race, type of culture, geographical area or historical period", have a source, a common, archetypal origin. A potential systematization of them has in view the differentiation between the paradigmatic plan (of phonetic vocabulary) and the syntagmatic one of the musical discourse, so that the so-called sound archetypes are identified and analyzed in order to use them in creation (Anghel 2018, 20).

As well as in literature, musical postmodernism relies heavily on quotation, which, in modernism, appears sporadically - in Stravinsky (Pulcinella) or Berg (Violin Concerto) A musical phrase, a subject in a composition belonging to other times are quoted and then processed by opposition, development, comparison, etc. However, the musical language offers the possibility of vertical overlap or the simultaneous presence of the quotation and of the new sound material, a possibility in which literary language is lacking. For example, in the sheet music of the Schlachthof $V$ (Slaughterhouse 5) opera by Hans-Jürgen von Bose, on the musical stage for the two synthesizers and the sampler (p. 7), we can see the graphic notations of the song of birds, but also quotations from Verdi's Requiem and from Mozart's Requiem (the passage Dies irae); whereas the first sounds like a defective plate of the gramophone, the second is processed to sound, as the composer specifies it in the score, sounding as in the original. Other sounds accompany the movement of the characters, the synthesizer simulating the noise produced by an airplane, the sound art appearing here much more complex than the text of American Kurt Vonnegut about the bombing of Dresden in his novel of 
the same title (Saughterhouse Five). The title of Von Bose's work, representative of the direction of the New Simplicity, refers to a slaughterhouse in Wiesbaden transformed into a cultural centre. The two-art works send out a similar message: Vonnegut, who took part in the bombing, is trying to deal with his traumatic memory and find out a solution: he will imagine a time travel into another dimension in which the bombing never took place. Von Bose chooses to deal with trauma on the same temporal level through a vertical structure which resembles a hypertext. The distorted Verdi score can be heard simultaneously with the noise made by the airplane which wrecks havoc upon the German city. The soothing melody of Mozart's Dies Irae can be heard simultaneously with Von Bose's own music rendered by the synthesizer. The title too refers to the transformation of a place of death into one of spiritual celebration.

We notice hear a distribution of the sound material along the vertical axis, which, however, is not derived from the main tune, as in the harmonic distribution of voices, but more like the spatial distribution of links in a hypertext (Fig. 1). Von Bose's music and Vonnegut's novel coexist without an express link between them. They could be represented like the brown and the blue trajectories in Fig. 2. However, there is an allusive relationship among, not two, but three elements of the score, as in Fig. 1: The Verdi quote refers to a similar musical genre - Mozart's Requiem -, to the noise of the bomber, and to Von Bose's song of birds processed by the synthesizer, which is the counterpoint of nature's soaring creatures in the sky, but as messengers of life and harmony. The glissando Tritone, modulated with the pitch wheel controlling the synthesizer in the third bar is also linked with the rest, because what the composer does is to slide from one unit of sense (novel/ opera, bomber/ birdsong, death/ requiem) to the other. An initial archetype of death is sliding under other signifieds through attraction, difference or similarity.

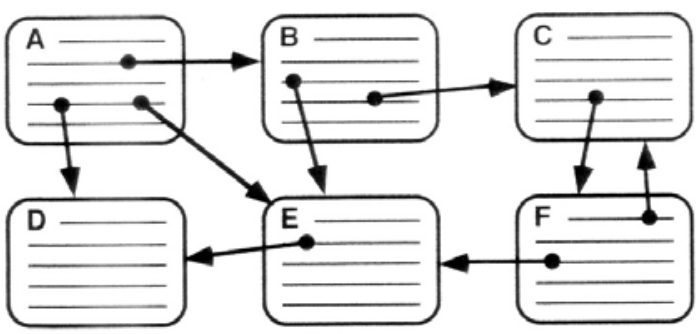

Fig. 1. Hypertext

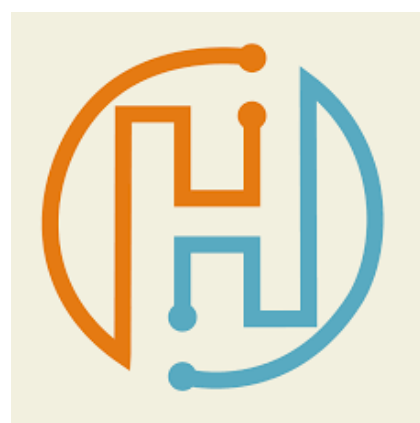

Fig. 2. Hypertext 
Even more appropriate to the essence of contemporary music is Martin Iddon's interpretation of The Dissolution of the Avant-Garde, which insists on the recovery of the importance of the individual object and of the verticality of its "declension". The art object, the musical composition, is no longer evolutionarily structured, communicating along the axis of time a certain message, a narrative, such as Peer Gynt's journey into space and spiritual transformation. At the same time, the stasis effect and the minimalist atomism are overcome by a paradigmatic, vertical expansion of a leading idea (here, death and resurrection), which is similar to the chords performed by the voices in the harmony of mainly tonal music.

However, in the Bose example, the elements brought together are heterogenous. We may say that the intertextuality of postmodernist music has become possible through the deconstruction of the traditional rules of composition. Here, the tritone consists of ... a book, a slaughterhouse striking the key of death and a musical genre. All of them maintain their independent semantic content, and yet they also make sense together, in this score. Iddon cites the chapter "Signature, Event, Context" in Jacques Derrida's book, Limited Inc., where he talks about the autonomy of the signature that does not depend on the presence of the signatory, being reproduced on different dates in different contexts, retaining its significance.

In the case of Von Bose's work, there is created a distance but also an affinity of meaning between the victimization implied by the destination of the construction (the slaughterhouse, where Vonnegut's protagonist is held prisoner) and the divine punishment on the Day of the Wrath of God (the Dies Irae of the Requiem), between the transformation of the destination of the building and the victory over death through the beauty and duration of the music about death. All these meanings are co-present.

By insertion into another musical work, a quotation used to break up the linearity of the respective score, interrupting the composer's message. On the contrary, in the case of Von Bose, for example, the quotation is introduced by a keyboardist (sound designer), the conception of the composition being separated from the technology of sound production, with the composer giving up on his claim as sole author. At the same time, the quotation is subjected, as Iddon writes, to a transcoding, transduction, a language serving as the basis of another, above another, dissipating in it or being constituted by it (Iddon 16). This effect, he says, is similar to polyphony.

Finally, Carl Dahlhaus sees the disappearance of the consonant ban imposed by Schönberg as a return to something akin to harmony and counterpoint stemming from the principle of tonal polarities in the 1960s, yet not as major / minor distinction but rather as an osmosis of chords, a sphere or a tonal field 
(Dahlhaus 1978). The avant-garde is being left behind, all these tendencies pointing to a return to previous modes of composition, yet the return is never complete.

We are going to examine some contemporary variants of this vertical recovery of the narrative of the thematic developments in classical music, specifying that the existence of precedents does not justify on the part of critics such as Norris the rejection of the term of postmodernism as a distinct stylistic period. The term, however, applies to contemporary music aware of tradition and not to the minimalist music which Norris comments upon under the inappropriate period term of postmodernism.

For some time now we can even say that we find ourselves in a postpostmodernity which, as is always the case in the history of styles, establishes affinities with the precedent of its previous period, that is, the post-romanticism of the late 19th century: Debussy's fascination with the sensoriality of the oriental, autonomous sound, redeemed from time, the study of sounds from the point of view of acoustics (see now the timbre music that exploits the physical properties of the sound) or, as I mentioned earlier, the presence of quotes. The composers of the New Simplicity are even aware of this, adopting labels such as New Romanticism or New Expressionism.

When it comes to archetypal music, even the primary sound material represents monads of meaning, concentrated narratives, myths, and stylistic pluralism being associated with multimedia language - a mix of sound, image, and text.

Here are some arguments in support of our position regarding the complexity of contemporary music, sometimes contrary to its own definition (The New... Simplicity)

\section{New Trends}

\subsection{The New Complexity}

Brian Ferneyhough is the representative of the School of New Complexity, which, perhaps, took its name from the vision of the universe taken by the New Physics which can be summed up as a combination of chaos and determinism. Steering a middleway between the severe determinism of Viennese modernists and the chaos of minimalists or Happening music of the 1950s, the composers of the New Complexity use microtones, harmonics that yield shadows of sounds, tuplets (notes with a varied number of divisions) distributed on superimposed levels. In this case, we speak of irrational rhythm, irregular rhythm, contrarithm. The notation is very 
complicated, and the interpretation very difficult. Short Shadows II, a guitar piece, is an example thereof.

\subsection{The New Simplicity}

The term "New Simplicity" was introduced by Wolfgang Becker in 1977, and defined as follows: "The new simplicity is an experience of contemporary music observable in many countries: the elementary simplification of the soundscape and the transfer of the complex structure into the internal musical form and interpretation."

A more elaborate definition would be given by pianist and composer Aribert Reimann (Reinmann 1979, 25), and the summer courses in Darmstadt in 1978 led to the emergence of a working group who were striving to bring music back into contact with the audience from which the avant-garde had broken loose, to create a new musicality, romantic, accessible, reverent to tradition (an inclusivist one, contrasting with avant-garde exclusivism). Among them: Hans-Jürgen von Bose, Wolfgang von Schweinitz and Wolfgang Rihm. Other labels assumed are: "New subjectivity" (neue Subjektivität), "new interiority" (Neue Innigkeit), "New Romanticism", "New Sensuality", "New expressiveness", "New classicism" and "New tone".

The adherents to this combination of electroacoustics and the art of sound are growing in number, being dissipated in different countries.

Joep Franssens aims to recover the transcendental propensity of the ancients who believed in the existence of an orchestrated universe, built by the Demiurge according to the Harmony of Spheres:

John Tavener, the best-known British composer of recent decades, has transposed into music the affective and visionary effect of his conversion to Eastern Orthodoxy. He wants to paint with sounds, giving the fabrics sound plasticity, translucency, symbolic significance.

The Lamb, a choral miniature dating back to 1982, for choir without accompaniment, was followed by the Light Icon (1983) - a true sonic showcase, and, later, by the Orthodox Vespers for priests, choir and bells, and the Thanksgiving Acatists (1987).

The Protecting Veil of 1987, in which the composer confesses that he tried to capture something of the cosmic power of the Mother of Jesus, narrates in the first section the life of the Virgin from the Annunciation to the Assumption. Her voice is performed continuously by the cello accompanied by strings, the sound having an exceptional purity and conjuring force. 


\subsection{Spectral Music}

Named by Hugues Dufourt in 1979, spectral music explores the timbral qualities of sound, the colour spectrum between higher harmonics and noise. Concerned with releasing music from the contextual and hermeneutic relationships in which it is often introduced (mathematical structure of language, quantum philosophy, thematicism and literature, etc.), Gérard Grisey pushes it into an older, purely physical, acoustic approach benefiting from the explosion of sound technology (sound recording and digital analysis). Nevertheless, the sound is invested with metaphoric meaning, Ewa Schreiber (Schreiber 2016) interpreting Grisey's aesthetics as governed by the conceptual metaphor of sound organism. His study of sonic objects takes into consideration the following criteria: mass, dynamics, harmonic timbre, melodic profile, mass profile, grain and allure. He thinks of sounds in terms of the grain which characterises a tissue or a mineral. Sounds of cohesive grain may be rough, matt or smooth, while sounds of discontinuous grain are sick, compressed or thin. The allure refers to the fluctuation of sound (vibrato). Grisley is interested in the organic feature of sound matter, comparing them to breathing, the beats of the heart, or footsteps, music interacting with the listener's body according to its biological rhythms. His aesthetic vision is a sort of sound physiology. "Modulations", "Transitories" or "Périodes" illustrate his notion of fuzzy periodicity (period structures marked by slight fluctuations).

\subsection{Archetypal Music}

Regardless of the acceptation of the concept of archetype - as an original image, from a psychic, mythical or cultural source - the music that lays claims to this tradition is profound and promises a holistic vision, obtained through the use of several languages and media channels. The visual/auditory interface, realized by spectral processing of both sensory materials, is at the same time a teleological articulation, meant to convey a certain message, having nothing in common with the chaotic happening or the avant-garde collage. Dediu's ontological model shows the persistence of the archetypal element through the entire musical discourse (structuring it, guiding it to a certain finality), despite the application of the operators of attraction, difference or similarity

Archetypal music is usually the creation of erudite musicians, it is based on a teleological project and formal complexity which justifies the fact that it is commonly accompanied by the theoretical considerations of the composers themselves. Here is Logan's key to the interpretation of her Charon's Pantheon: 
A union of archetype with structure, Charon's Pantheon is a collection of 13 goddesses, represented in life-size sculpture and 70 minutes of electroacoustic music which fuses the tangible with the intangible, suprarational with the rational, and the infinite and unknowable with the absolute, resulting in an experience that taps into the curve of a waveform as it exists in time, stretching back to pre-Euclidean geometry and spiritual concepts of unity in number, symbol, divinity, and harmony (Logan 2015, 79-80)

One of the most impressive multimedia sequences is the sound and image of the Goddess of Death (figure 3).

The concept of "psycho-acoustic space" makes us think of Gaston Bachelard's psycho-physics, a poetician of imaginary spaces, who also associated dream projections with the four elements used by Plato's Demiurge for the construction of the universe according to a range of tetrads - the four notes also symbolizing the four elements. Bachelard, however, followed the philosopher Wilhelm Wundt, whose psychology was also psycho-physical - a study of the harmony between the physical and the mental picture - a psychology that underpinned impressionistic aesthetics. We are, again, in the area of post-romantic poetics, of the late nineteenth-century 'isms. Does not this association between the archaic imaginary (mythical, archetypal) and formal experimentation remind us of the dominant figure of the era - Richard Wagner?

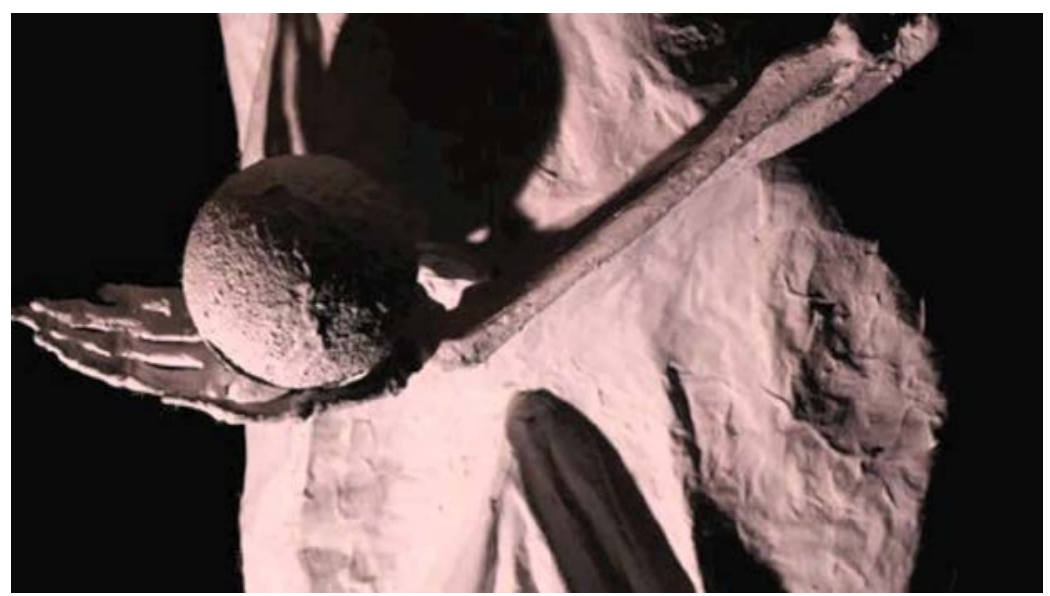

Fig. 3. Jennifer Logan: "Goddess of Death" 


\section{Conclusion}

Whereas the musical formalism of the last century was a synergetic system, in the sense that all the elements of the score contributed to the overall structrure, a new form of holism can be identified in post-avantgarde movements, such as those briefly surveyed in this paper. Metamusic, corresponding to the metanarratives of literary postmodernity, are not missing, Andrieseen crossing even the border over to philosophy and politics in De Staat, II Principe, or II Duce. The most significant change, however, seems to us to be some composers' response to the call of ancestry, of that syncretism which set up harmony as the very principle of the universe. Form is once more charged with meaning, the electro-acoustic music which capitalized on mathematical language and operators in Xenakis giving way to correlations between the acoustic spaces, geometry and archetype, to what Jennifer Logan calls the congruence between musical parameters and a conception of spirituality (Logan 2015, 79).

\section{References}

Anghel, Irinel. 2018. Orientări, direcții, curente ale muzicii românești din a doua jumătate a secolului XX [Orientations, directions, currents of Romanian music from the second half of the 20th century]. București: Eikon.

Bennett, David. 2005. "Postmodern Eclecticism and the World Music Debate: The Politics of the Kronos Quartet". Context, Issue 29- 30: 5-15.

Dahlhaus, Carl. 1978. "Formenlehre und Gattungstheorie bei A. B. Marx." In: SieversFs 29-35. [Rilm 78- 6059.] Forchert: Arno.

Derrida, Jacques. 1972. Signature, Event, Context, in Limited Inc., Evanston II: Northwestern University Press

Erlmann, Viet. 1996. "The Aesthetics of the Global Imagination: Reflections on World Music in the 1990s". Public Culture 8: 68-87. The University of Chicago.

Iddon, Martin. 2008. "The Dissolution of the Avant-Garde." Journal for New Music and Culture, Vol. 1, No. 1. Lancaster University.

Logan, Jennifer. 2015. "Archetypal Congruencies between Number and Mysticism found in the Sacred Electro-acoustic Music of Charon's Pantheon." Journal of Humanities \& Arts, 2(2): 79-94. Athens.

Norris, Christopher. 2000. "Post-modernism - a guide for the perplexed." In Understanding Contemporary Society: Theories of the Present, ed. by Gary Browning, Abigail Halcli, Frank Webster, 25-45. London: Sage Publications. DOI: http://dx.doi.org/10.4135/9781446218310.n2

Schreiber, Ewa. 2016. "Metaphor and the concept of sound in contemporary music". In Metaphor and Communication, ed. by Elisabetta Gola and Francesca Ervas. Amsterdam: John Benjamin's Publishing Company. 